\title{
STUDY REGARDING THE INFLUENCE OF THE UNEMPLOYMENT RATE OVER NON-PERFORMING LOANS IN ROMANIA USING THE CORRELATION INDICATOR
}

\author{
Iulia Iuga ${ }^{1}$ \\ Ruxandra Lazea ${ }^{2}$
}

\begin{abstract}
In this paper it is studied the influence of unemployment rate on non-performing loans in Romania. The following issues are presented: the definition of nonperforming loans, the criteria used by Romania in the definition of nonperforming loans (NPL), Romanian legislation that regulates nonperforming loans, the causes leading to nonperforming loans and the national regulates regarding unemployment. The paper contains also graphic representation of the analysis: 1) nonperforming loans in the world, 2) credits in Romania by the five risk classes for years 20062011; 3) nonperforming loans based on the unemployment rate in Romania. Finally, we established the correlation between unemployment rate and nonperforming loans in Romania, with the usage of the "Pearson" correlation coefficient.
\end{abstract}

Key words: nonperforming loans, unemployment rate, analysis, correlation coefficient.

JEL Codes: G21, C44.

Introduction

"There are various definitions of this term depending on the type of loan and on the lender's policy. When the payments of interests and principal are past due by 90 days or more, a loan is considered nonperforming and the debtor is insolvent" (Dictionary of Banking Terms - Third Edition - Thomas Fitch).

Loan portfolio quality deteriorated during the time period 2009-2011 and the banks recorded high levels of nonperforming loans. Repayment behavior of the borrowers' bank records negative effects. The causes are numerous, including the decreasing of living standards in conjunction with an increased unemployment rate. In the same period a significant increase in unemployment rate has been recorded and also in the number of unemployed. This paper presents bank loan portfolio deterioration and causes that led to this deterioration.

An empirical study is included to demonstrate how the unemployment rate and nonperforming loans are connected.

We developed a research hypothesis Pearson correlation coefficient and we studied the situation of the Romanian banking system during 2008- 2011. With Pearson correlation coefficient we want to study if there is a correlation between unemployment rate and nonperforming loans in Romania case.

\section{Literature review}

Despite a surge in the research efforts put into modeling credit and default risk during the past decade, few studies have incorporated the impact that macroeconomic conditions have on business defaults (Carling, Kenneth; Jacobson, Tor; Lindé, Jesper; Roszbach, Kasper, 2007).

\footnotetext{
1 “1 Decembrie 1918” University of Alba Iulia, Romania,e-mail:iuga_iulia@yahoo.com

"“1 Decembrie 1918” University of Alba Iulia, Romania, e-mail: ruxandra_rdvc@yahoo.com
} 
Although credit history scoring offers benefits to lenders and borrowers, failure to consider situational circumstances raises important statistical issues that may affect the ability of scoring systems to accurately quantify an individual's credit risk (Avery, Robert B.; Calem, Paul S.; Canner, Glenn B., 2004).

\section{Nonperforming loans. Definition.}

There is no agreed upon definition at the level of the European Union, but there is a definition recommended by the International Monetary Fund.

For a better data comparability, the IMF Guide (Financial Soundness Indicators: Compilation Guide) recommends that loans and other assets be classified as nonperforming when the payments, representing the principal, and the interests are past due by 90 day or more.

In addition, non-performing loans will also include those loans with a debt service of less than 90 days, days that are acknowledged by the national legislation as being non-performing when there is clear evidence of default (for example, in case of bankruptcy).

The 90 days criterion represents the most common practice in various countries to determine non-performing loans.

The table below lists a few countries and the deadline upon which loans are considered nonperforming:

Table no. 1

Timetable for loans to become non-performing

\begin{tabular}{|c|c|}
\hline \multirow{3}{*}{$\begin{array}{l}\text { Past due days for principal and } \\
\text { interests: }\end{array}$} & $\begin{array}{l}\text { - >90 days: } 12 \text { countries (Romania; } \\
\text { Bulgaria, Cyprus, Greece, Macedonia, } \\
\text { Serbia, Hungary, Poland, Czech Republic, } \\
\text { Ukraine, Leetonia, Austria) }\end{array}$ \\
\hline & $\begin{array}{l}>60 \text { days: } 2 \text { countries (Estonia, } \\
\text { Lithuania) }\end{array}$ \\
\hline & $\begin{array}{l}\cdot>30 \text { days: } 1 \text { country } \\
\text { (Russia }>30 \text { days }- \text { legal persons } \\
\quad>60 \text { days }- \text { natural persons) }\end{array}$ \\
\hline
\end{tabular}

Source: National Bank of Romania, Financial Stability Report 2008-2011

\section{legislation.}

\section{Criteria used by Romania in defining non-performing loans (npl). Romanian}

Non-performing loans are the loans that generate the highest expense for the risk management of a bank. The maximum level of costs is reached in the case of loans accounted as loss, for which nothing can be recuperated and which are covered from the reserve fund or the risk fund. Covering for these loans leads to a corresponding reduction of the bank's assets and liabilities, and therefore to a reduction of the activity load.

\section{Prudential methodology}

NBR Regulation no. 3/2009, as amended:

$>$ Debt service (number of overdue days for the scheduled payment);

$>$ Initiating the legal procedures (at least one of the following measures will be taken to recover debts: a. obtaining a court decision to initiate bankruptcy procedures; $b$. starting the enforcement procedure against natural or legal persons);

$>$ Financial performance (reflecting the economic potential and the financial solidarity of an entity resulted after analyzing a set of quantitative and qualitative factors);

$>$ Declassing by contamination (taking into account the weakest of the individual classification categories);

$>$ Outstanding loan balance and associated interests. 


\section{Accounting methodology}

(EU Directives applicable to IC, Non-Banking Financial Institutions, Deposit Guarantee Fund in the Banking System of 19.12.2008)

* Debt service (number of overdue days for the scheduled payment)

* Initiating the legal procedures (at least one of the following measures will be taken to recover debts: a. obtaining a court decision to initiate bankruptcy procedures; $b$. starting the enforcement procedure against natural or legal persons).

\& Principal payments overdue by more than one day (principal refers to: the amounts loaned by creditors to borrowers in the form of a loan capital, including those that may fall within this category in case the borrowers' obligations included in the financing commitments and in the guarantee commitments become contingent, as well as the deposits placed at credit institutions).

\section{Causes that lead to the occurrence of non-performing loans}

The major cause of problems regarding the inability to pay back loans and of the quality drop is related to:

\section{$>\quad$ the standards of loan;}

$>\quad$ poor management of the loan portfolio;

$>\quad$ a lack of attention to changes in the economic circumstances, which may lead to a deterioration of the loans granted by the bank.

The main occurrence cause of non-performing loans continues to be the incompetence and carelessness of the bank's personnel. The most frequent mistakes made by the bank officers are:

- Inappropriate interview;

- Inadequate financial analysis;

- Poor guarantee of the loan;

- Inaccurate and incomplete documentation;

- Quality control and monitoring of clients.

Another cause is the debtor's inability to repay the loan.

\section{National regulations regarding unemployment}

According to Law no. 76/16.01.2002, an unemployed person is the individual who meets all the following conditions:

a) is looking for a job and is aged between 16 and the retirement age if he/she meets the conditions for retirement;

b) has the health and the physical and mental abilities to be fit for work;

c) has no job, no incomes or incomes earned from authorized activities below the unemployment benefit to which he/she is entitled according to law;

d) is available to start working immediately after a job is found;

e) is registered with the National Agency for Employment or with another employment services' provider, which operates under the law. conditions:

Unemployed persons receive an unemployment benefit if they meet all the following

a) have a minimum contribution period of 12 months in the last 24 months preceding the date of the unemployment file's registration;

b) have no incomes or have incomes lower than the unemployment benefit, earned from authorized activities;

c) don't qualify for retirement, according to law;

d) are registered with the employment agencies in whose jurisdiction they have domicile or, as the case may be, they reside, if they had a job or earned incomes in that jurisdiction. 
The unemployment benefit is granted for periods of 6 months to 15 months and the sum is a fixed amount, tax free, received monthly, representing $75 \%$ of the gross minimum wage.

\section{Analysis of non-performing loans at global level}

\section{Europe: Emerging and developing economies - Central and Eastern Europe}

Nonperforming loans have significally increased in the Central and Eastern Europe from the beginning of the crisis till present day.

Table no. 2.

Nonperforming loans to total loans in emerging and developing economies

\section{Central and Eastern Europe}

\begin{tabular}{|l|r|r|r|r|}
\hline $\begin{array}{c}\text { Nonperforming loans to total loans in emerging } \\
\text { and developing economies Central and Eastern Europe }\end{array}$ & 2007 & 2008 & 2009 & 2010 \\
\hline Albania & 3,4 & 6,6 & 10,5 & 13,9 \\
\hline Bosnia and Herzegovina & 3 & 3,1 & 5,9 & 9,2 \\
\hline Bulgaria & 2,1 & 2,5 & 6,4 & 11,9 \\
\hline Croatia & 4,8 & 4,9 & 7,8 & 11,2 \\
\hline Hungary & 2,3 & 3 & 6,7 & 9,1 \\
\hline Latvia & 0,8 & 3,6 & 16,4 & 19 \\
\hline Lithuania & 1 & 4,6 & 19,3 & 19,7 \\
\hline Macedonia, FYR & 7,5 & 6,7 & 8,9 & 9 \\
\hline Montenegro & 3,2 & 7,2 & 13,5 & 21 \\
\hline Poland & 5,2 & 4,5 & 8 & 8,8 \\
\hline Romania & 2,6 & 2,8 & 7,9 & 11,9 \\
\hline Turkey & 3,6 & 3,8 & 5,6 & 3,8 \\
\hline
\end{tabular}

Source: created based on data from International Monetary Fund, Global Financial Stability Report, Meeting New

Challenges to Stability and Building a Safer System, pg. 213

The chart corresponding to table 2 is presented below:

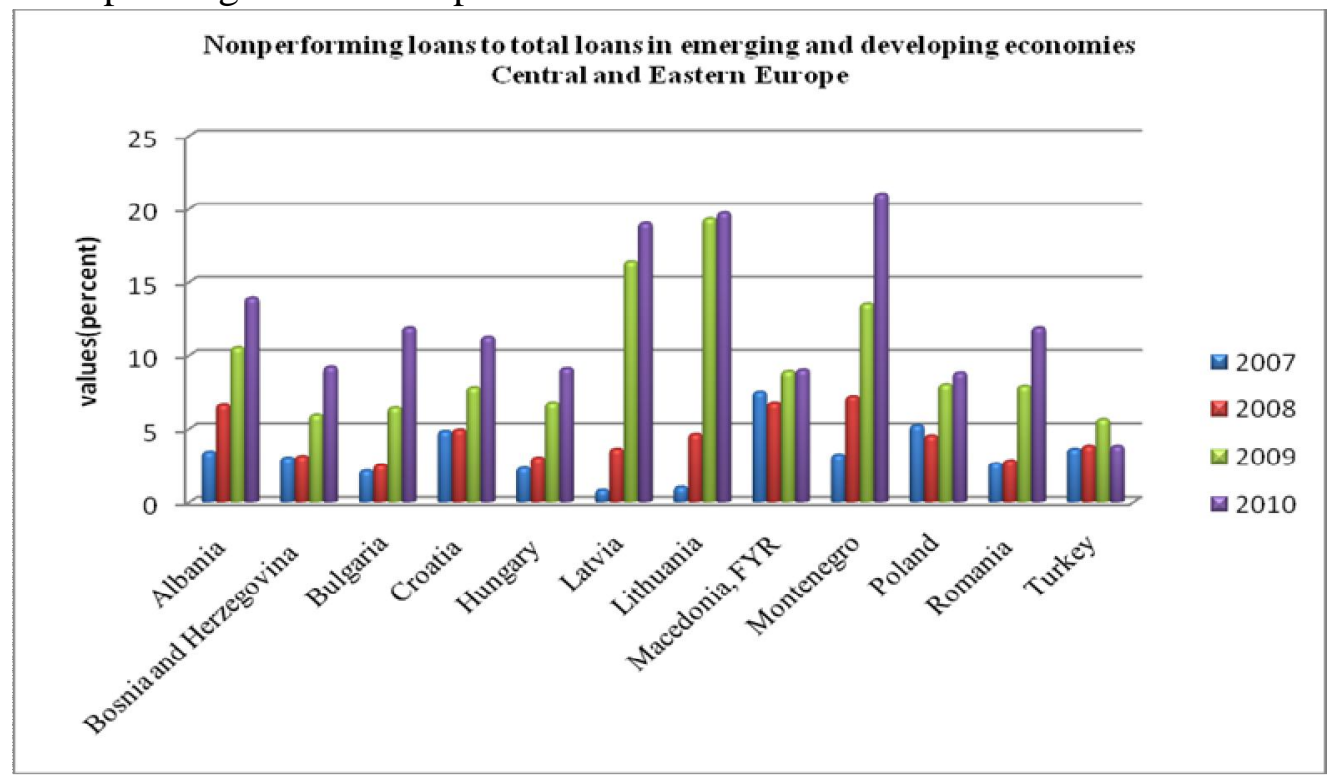

Figure no. 1 


\section{Source: created based on data from International Monetary Fund, Global Financial Stability Report, Meeting New} Challenges to Stability and Building a Safer System, pg. 213

From september 2008 global crisis has extended also to the emerging countries from Europe. In a few weeks, the global financial markets begin to have major problems and also the international commerce (exports and imports).

Western European banks have played an important role in providing capital flows to the countries from Emerging Europe before the crisis and after. Also, these banks helped stabilize this region during the crisis. On the entire period, all foreign banks remained in the region and had a stabilizing effect.

Higher capital and funding costs in Lithuania and high nonperforming loans ratio in Romania are contributing to tighter lending standards for corporate loans.

In Romania, the authorities imposed rules regarding banks exposal. These rules have been respected also by the western banks with offices across the country.

In Romania, an important decrease in capital inflows and international reserves had been recorded. Romania has entered into an FMI program in May 2009.

There are only two countries that share of nonperforming loans in total loans over $15 \%$ in 2009: Latvia and Lithuania.

Crisis in 2008/09 and the boom that preceded and created problems to the banks: many loans were granted during the economic boom and after the emergence of the economic crisis (when increased bankruptcies, the number of the bankruptcies' of firms, increased unemployment rate, etc.) existing amounts of recorded loans have recorded payment problems. A high ratio of bad loans to total loans increased. A negative influence over the loans which then turned into loan losses had the securities in the form of housing. Before the crisis them had a price and after the crisis fell down even more heavily in some countries.

In 2010 an increase of nonperforming loans for each analyzed country are registered.

\section{Advanced economies}

Even from the beginning of the crisis the increase of the loans was slow. This fact is the result of a weak request (reduced application for loans), the increase of the provisions and the tightening of the conditions for giving loans.

Table no. 3 .

Nonperforming loans to total loans in Advanced economies

\begin{tabular}{|l|r|r|r|}
\hline Advanced economies & $\mathbf{2 0 0 7}$ & $\mathbf{2 0 0 8}$ & $\mathbf{2 0 0 9}$ \\
\hline Australia & 0,2 & 0,8 & 1,1 \\
\hline Austria & 2,2 & 1,9 & 2,3 \\
\hline Belgium & 1,1 & 1,7 & 2,7 \\
\hline Canada & 0,7 & 1,1 & 1,2 \\
\hline Czech Republic & 2,8 & 3,3 & 5,3 \\
\hline Greece & 4,5 & 5 & 7,2 \\
\hline Hong Kong SAR & 0,8 & 1,2 & 1,5 \\
\hline Ireland & 0,8 & 2,6 & 7,5 \\
\hline Israel & 1,4 & 1,5 & 1,5 \\
\hline Italy & 4,6 & 4,9 & 6,2 \\
\hline Japan & 1,4 & 1,6 & 1,8 \\
\hline Korea & 0,7 & 1,1 & 1,5 \\
\hline Norway & 0,5 & 0,8 & 1,1 \\
\hline Portugal & 1,5 & 1,9 & 2,8 \\
\hline Singapore & 1,5 & 1,7 & 2,3 \\
\hline Slovak Republic & 2,5 & 3,2 & 4,3 \\
\hline Slovenia & 1,8 & 1,8 & 2,3 \\
\hline
\end{tabular}




\begin{tabular}{|l|r|r|r|}
\hline Spain & 0,9 & 3,4 & 5,1 \\
\hline Sweden & 0,6 & 1 & 2 \\
\hline United Kingdom & 0,9 & 1,6 & 3,3 \\
\hline United States & 1,4 & 2,9 & 5,4 \\
\hline
\end{tabular}

Source: created based on data from International Monetary Fund, Global Financial Stability Report, Meeting New

Challenges to Stability and Building a Safer System, pg. 213

The chart corresponding to table 3 is presented below:

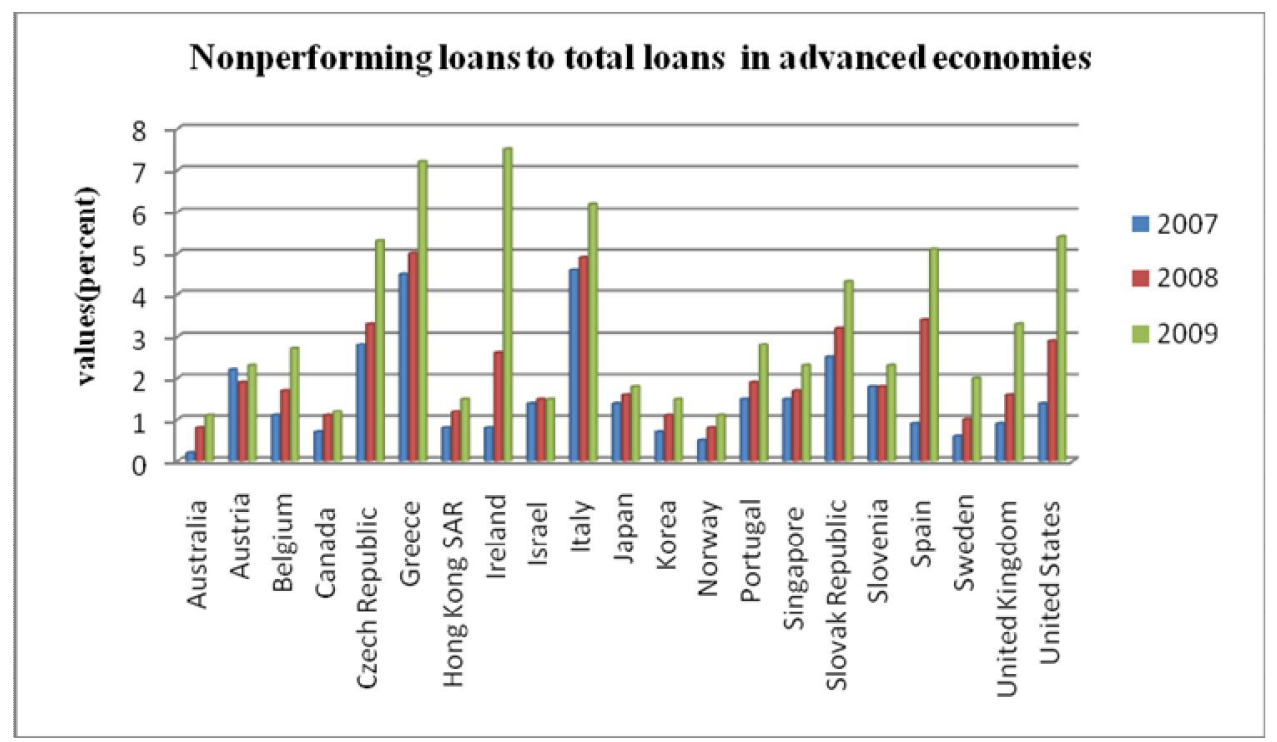

Figure no 2.

Source: created based on data from International Monetary Fund, Global Financial Stability Report, Meeting New Challenges to Stability and Building a Safer System, pg. 213

There are six countries that share of nonperforming loans in total loans over 5\% in 2009: Czech Republic, Greece, Ireland, Italy, Spain and United States. Toate țările analizate au înregistrat creşteri în portofoiul de credite neperformante. Some countries have recorded slow increases: Australia, Austria, Belgium, Israel; Japan; Korea, Norway, Canada. All analyzed countries have recorded increases in nonperforming loans portfolio.

\section{ASIA}

From the graph it is found that in all analyzed countries from this region (except Pakistan) it is shown a decrease in nonperforming loans from total loans during years 2007-2009, so that none of these countries (excluding Pakistan) does not record a higher percentage than 5\%.

Table no. 4.

Nonperforming loans to total loans in Developing Asia

\begin{tabular}{|l|r|r|r|l|l|}
\hline $\begin{array}{l}\text { Nonperforming loans to total loans in Developing } \\
\text { Asia }\end{array}$ & 2007 & 2008 & 2009 & 2010 & 2011 \\
\hline China & 6,2 & 2,4 & 1,6 & - & - \\
\hline India & 2,5 & 2,4 & 2,4 & - & - \\
\hline Indonesia & 4,1 & 3,2 & 3,8 & - & - \\
\hline Malaysia & 6,5 & 4,8 & 3,8 & - & - \\
\hline Pakistan & 7,6 & 10,5 & 12,6 & 14,7 & 15,4 \\
\hline Philippines & 5,8 & 4,5 & 4,6 & - & - \\
\hline
\end{tabular}

Source: created based on data from International Monetary Fund, Global Financial Stability Report, Meeting New Challenges to Stability and Building a Safer System, pg. 213 
The chart corresponding to table 4 is presented below:

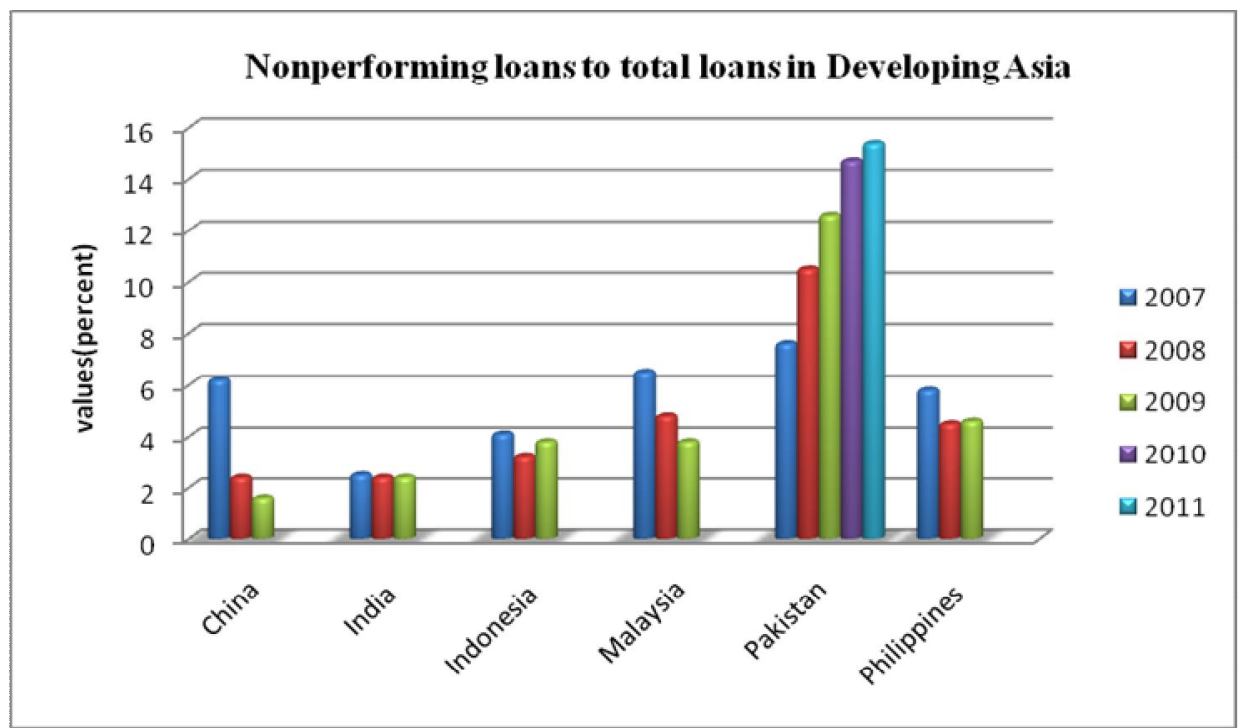

Figure no 3.

Source: created based on data from International Monetary Fund, Global Financial Stability Report, Meeting New

Challenges to Stability and Building a Safer System, pg. 213

Nonperforming loans are high or rising in Pakistan. China and Malaysia records a downward trend during 2007-2009 of nonperforming loans. In the same period India records a constant evolution and Philippines and Indonesia records light evolution fluctuation.

\section{Credit analysis in Romania in function of the five classes of risk in the years 2006-2011}

In the classification process of the loan portfolio for the clients in the non-banking sector, Regulation no. 3/2009 of the National Bank of Romania regarding the classification of loans and investments imposes the following classification:

- Standard loans - are the investments that don't involve risks in the management of the debt and are granted to reliable clients for good businesses;

- Loans under observation - are the loans granted to clients with excellent financial results, but who face challenges in paying the due installments and the associated interests for short periods of time;

- Substandard loans - are the investments with clear deficiencies and risks, which endanger the liquidation of debt, being insufficiently protected by the net value of the capital and / or by the borrower's ability to pay;

- Doubtful loans - their full repayment is highly uncertain due to existent conditions, values and collaterals, being practically unprotected or protected very little by the achievable value of the collateral;

- Losing loans are the loans that can't reimbursed to the bank. 


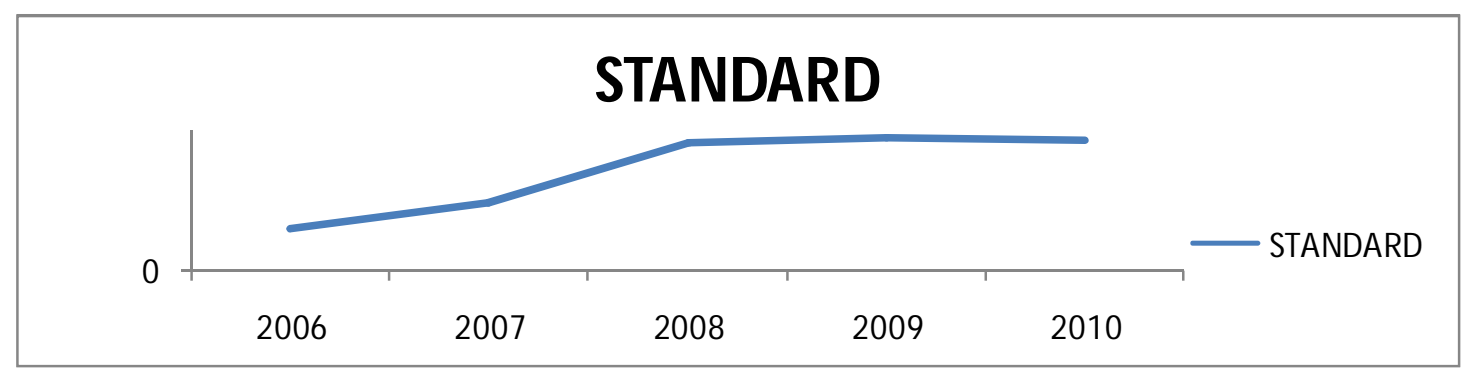

Figure no 4. - Standard credit situation in the years 2006-2010 in Romania

Source: created based on data from National Bank of Romania - Monthly bulletins, January - December 2006-2010

From the chart it can be observed that in the period 2006 -2008 "good" credits (namely standard) began to grow and with the appearance of the financial crisis, they have stagnation and even a decline in year 2010 .

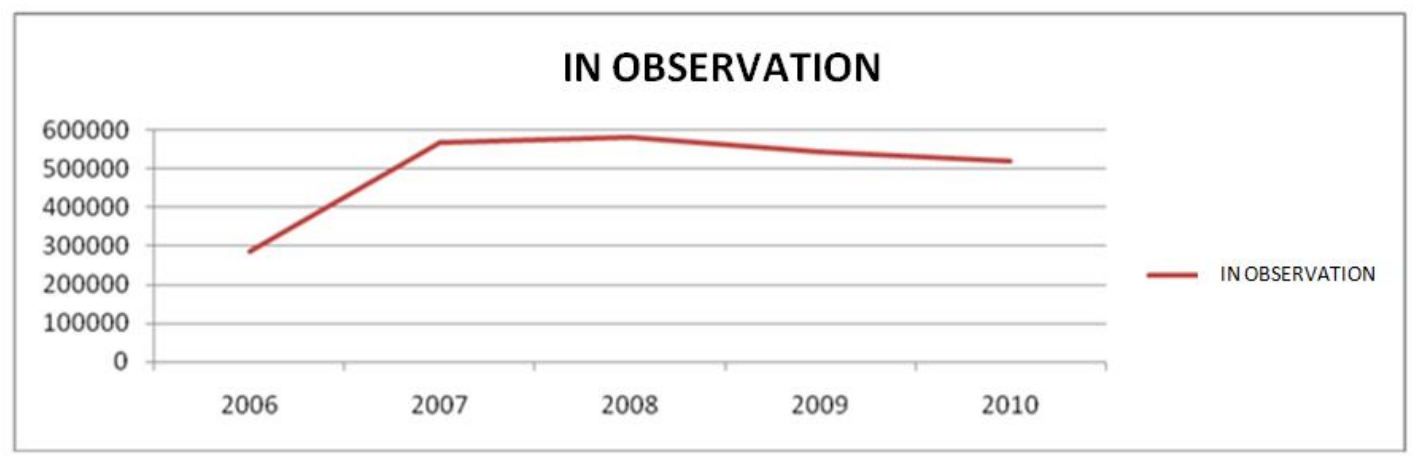

Figure no. 5.- Credit situation in observation in the years 20062010 in Romania

Source: created based on data from National Bank of Romania - Monthly bulletins, January - December 2006-2010

From the chart it can be observed that during 2006-2007 'relatively good' credits (namely in observation) began to grow, and since 2007, they stagnated until 2008 and even decreased in the years 2009 and 2010 .

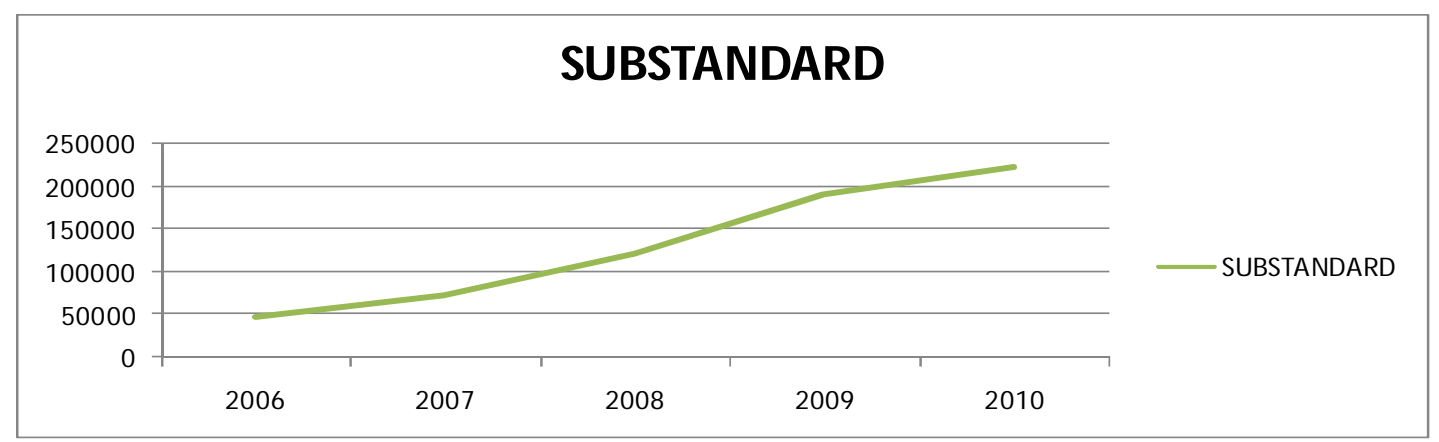

Figure no. 6. - State of substandard loans in the years 2006-2010 in Romania

Source: created based on data from National Bank of Romania - Monthly bulletins, January - December 2006-2010 


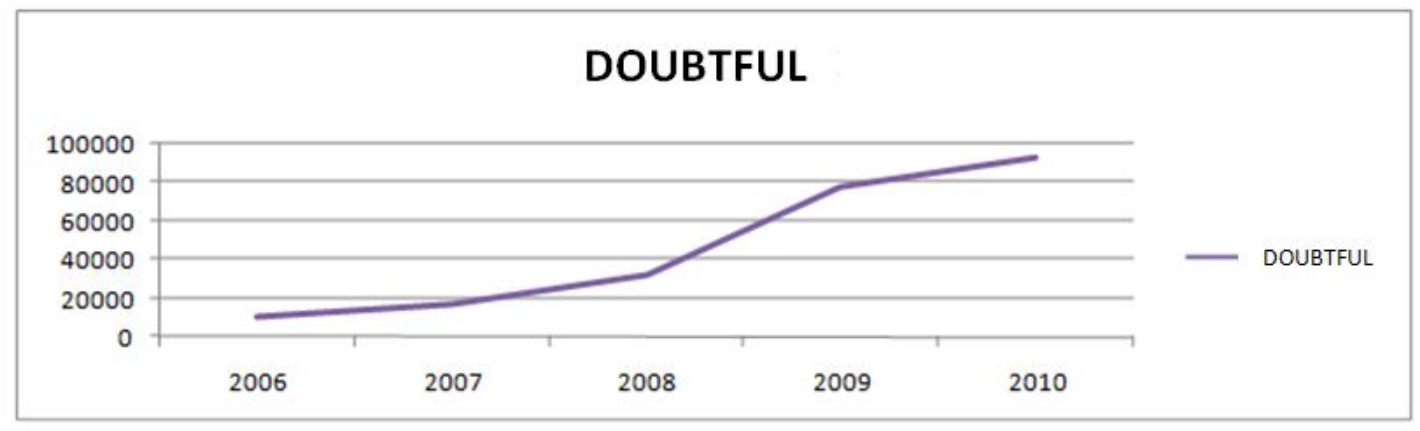

Figure no. 7- State of doubtful loans in the years 2006-2010 in Romania

Source: created based on data from National Bank of Romania - Monthly bulletins, January - December 2006-2010

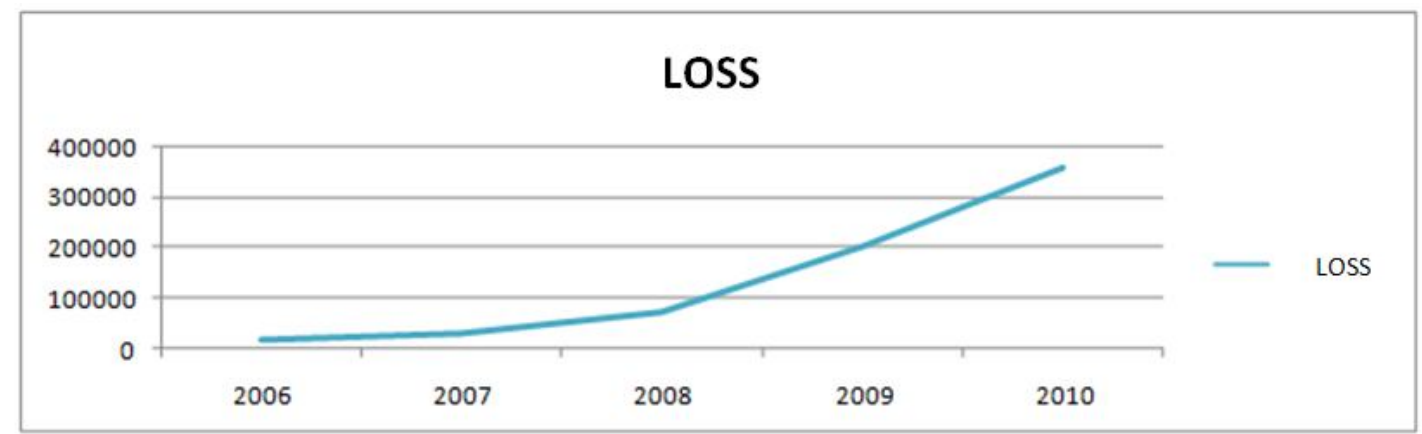

Figure no. 8. - State credit loss in the years 2006-2010 in Romania

Source: created based on data from National Bank of Romania - Monthly bulletins, January - December 2006-2010 the 2008.

From the charts no. 6, 7 and 8, results a sharp increase of nonperforming loans starting with

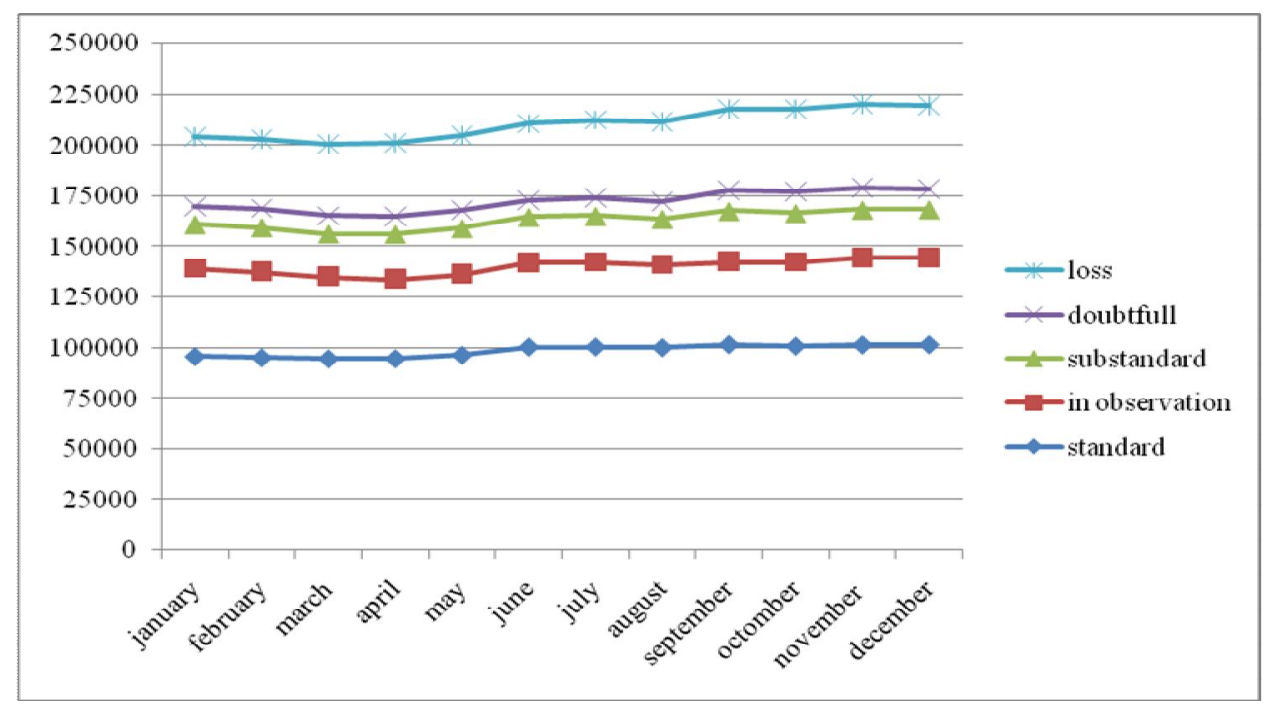

Figure no. 9. - State of credits in the year 2011 in Romania

Source: created based on data from National Bank of Romania - Monthly bulletins, January - December 2011

Though with a lower intensity compared with 2010, the deterioration of the loan portfolio of banks' balance sheets continued in 2011, the share of non-performing loans reached 14.3 percent at December 31, 2011, compared to 11.9 percent at 31 December 2010. 


\section{Nonperforming loans analysis according to unemployment rate in Romania}

In the year 2008 the unemployment rate increased from one month to another and the volume of nonperforming loans also increased. Unemployment rate grew during the period January to December 2008 with $5 \%$ and the rate of nonperforming loans in the same period increased by $75 \%$.

Table no. 5.

Pearson correlation coefficient between the evolution of the number of registered unemployed in 2008 and the volume of nonperforming loans in January 2008 - December 2008

\begin{tabular}{|l|l|r|r|}
\hline No. & Month & $\begin{array}{r}\text { Evolution of the number of } \\
\text { registered unemployed in 2008 }\end{array}$ & $\begin{array}{c}\text { Nonperforming loans in } \\
\text { 2008 (mil lei) }\end{array}$ \\
\hline 1. & Ian & 383,989 & 15169,20 \\
\hline 2. & Feb & 379,779 & 15152,40 \\
\hline 3. & Mar & 374,05 & 15699,40 \\
\hline 4. & Apr & 352,466 & 15894,80 \\
\hline 5. & May & 338,298 & 16298,90 \\
\hline 6. & Jun & 337,084 & 17814,10 \\
\hline 7. & Jul & 340,462 & 18029,00 \\
\hline 8. & Aug & 345,51 & 18594,10 \\
\hline 9. & Sept & 352,912 & 20914,30 \\
\hline 10. & Oct & 364,183 & 22346,00 \\
\hline 11. & Nov & 376,971 & 23946,80 \\
\hline 12. & Dec & 403,441 & 26480,40 \\
\hline
\end{tabular}

Source: created based on data from registered unemployment statistics operative situation issued by National Agency of Employment at 31 December 2010 and Monthly bulletins from January to December 2008 issued by National Bank of Romania

The chart corresponding to table 5 is presented below:

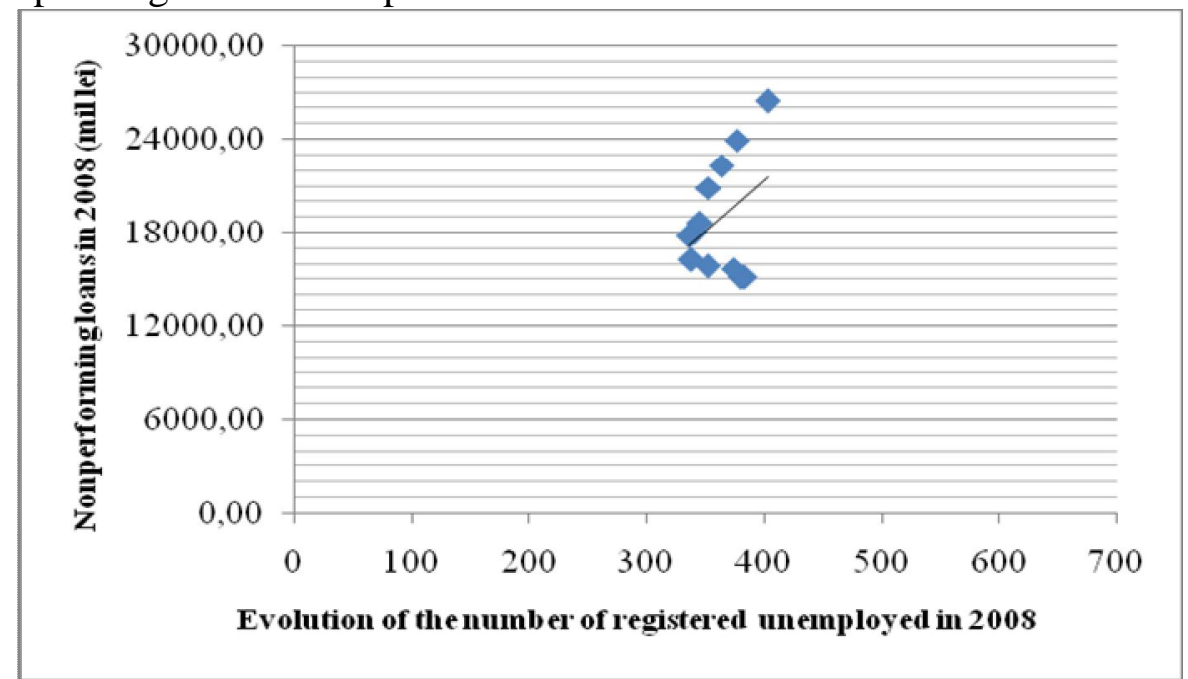

Figure no 10.

Source: created based on data from registered unemployment statistics operative situation issued by National Agency of Employment at 31 December 2010 and Monthly bulletins from January to December 2008 issued by National Bank of Romania 
Table no. 6.

Pearson correlation coefficient between the evolution of the number of registered unemployed in 2009 and the volume of nonperforming loans in January 2009 - December 2009

\begin{tabular}{|l|l|r|r|}
\hline No. & Month & $\begin{array}{c}\text { Evolution of the number of } \\
\text { registered unemployed in 2009 }\end{array}$ & $\begin{array}{c}\text { Nonperforming loans in 2009 } \\
\text { (mil lei) }\end{array}$ \\
\hline 1. & Ian & 444,907 & 30381,10 \\
\hline 2. & Feb & 477,860 & 32198,90 \\
\hline 3. & Mar & 513,621 & 33599,20 \\
\hline 4. & Apr & 517,741 & 35610,20 \\
\hline 5. & May & 526,803 & 36694,00 \\
\hline 6. & Jun & 548,930 & 37176,70 \\
\hline 7. & Jul & 572,562 & 39589,40 \\
\hline 8. & Aug & 601,673 & 41205,70 \\
\hline 9. & Sept & 625,140 & 43403,40 \\
\hline 10. & Oct & 653,939 & 45827,60 \\
\hline 11. & Nov & 683,123 & 47310,90 \\
\hline 12. & Dec & 709,383 & 46366,10 \\
\hline
\end{tabular}

Source: created based on data from registered unemployment statistics operative situation issued by National Agency of Employment at 31 December 2010 and Monthly bulletins from January to December 2009 issued by National Bank of Romania

The chart corresponding to table 6 is presented below:

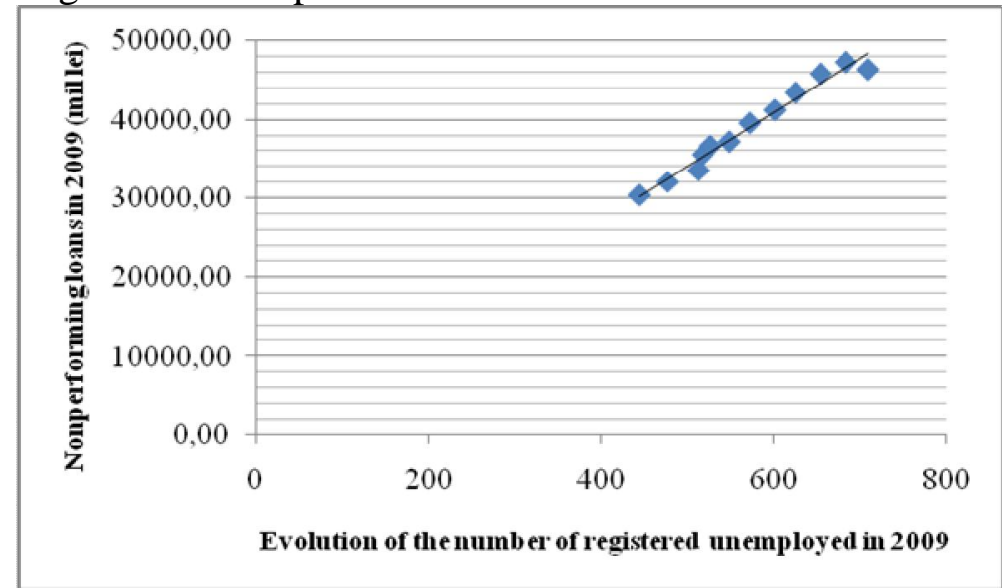

Figure no. 11

Source: created based on data from registered unemployment statistics operative situation issued by National Agency of Employment at 31 December 2010 and Monthly bulletins from January to December 2009 issued by National Bank of

Romania

In the year 2009 the unemployment rate increased from one month to another and the volume of nonperforming loans also increased. Unemployment rate grew during the period January to December 2009 with $60 \%$ and the rate of nonperforming loans in the same period increased by $52 \%$.

In 2010 from Romania's statistical data, results that the unemployment rate decreased from month to month, and the volume of nonperforming loans increased. Unemployment decreased in the period January to December 2010 with $15 \%$ and the rate of nonperforming loans from the same period increased by $34 \%$. The anomaly appears at the decrease of the unemployment rate, the fact that we will discuss in the following section. 
Table no.7.

Pearson correlation coefficient between the evolution of the number of registered unemployed in 2010 and the volume of nonperforming loans in January 2010 - December 2010

\begin{tabular}{|l|l|r|r|}
\hline No. & Month & $\begin{array}{r}\text { Evolution of the number of } \\
\text { registered unemployed in } 2010\end{array}$ & $\begin{array}{c}\text { Nonperforming loans in 2010 } \\
\text { (mil lei) }\end{array}$ \\
\hline 1. & Ian & 740,982 & 48534,90 \\
\hline 2. & Feb & 762,375 & 49126,70 \\
\hline 3. & Mar & 765,285 & 49294,50 \\
\hline 4. & Apr & 738,187 & 50198,40 \\
\hline 5. & May & 701,854 & 52310,00 \\
\hline 6. & Jun & 680,782 & 54224,20 \\
\hline 7. & Jul & 679,495 & 54767,90 \\
\hline 8. & Aug & 675,790 & 56374,60 \\
\hline 9. & Sept & 670,247 & 62485,20 \\
\hline 10. & Oct & 645,453 & 64108,80 \\
\hline 11. & Nov & 633,476 & 64752,80 \\
\hline 12. & Dec & 626,960 & 64986,30 \\
\hline
\end{tabular}

Source: created based on data from registered unemployment statistics operative situation issued by National Agency of Employment at 31 December 2010 and Monthly bulletins from January to December 2010 issued by National Bank of Romania

The chart corresponding to table 7 is presented below:

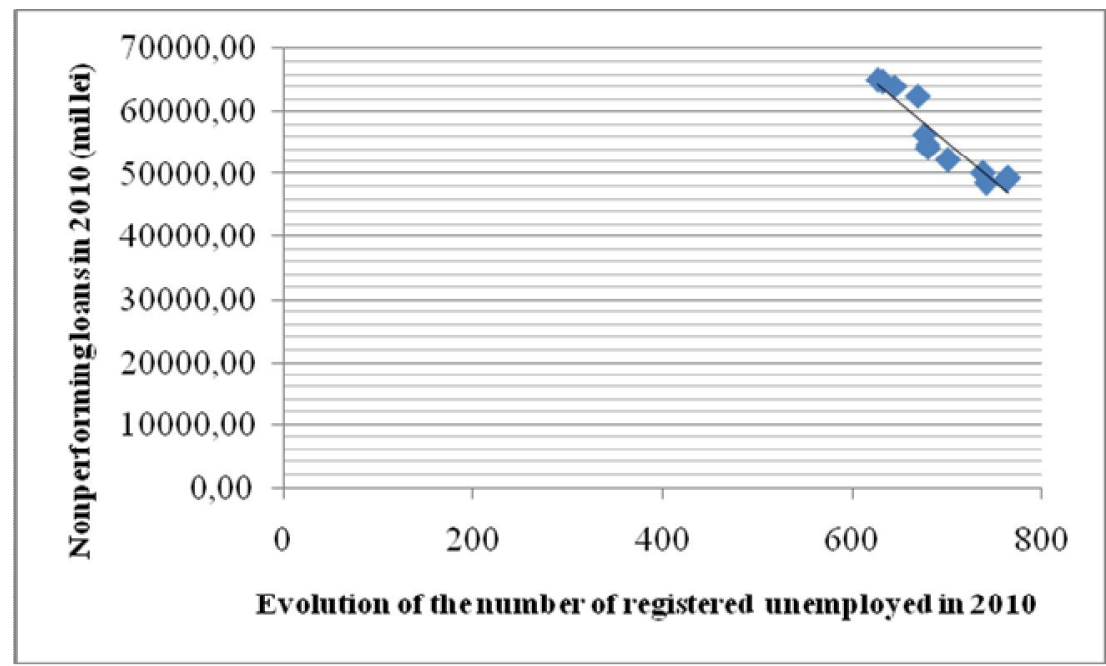

Figure no 12.

Source: created based on data from registered unemployment statistics operative situation issued by National Agency of Employment at 31 December 2010 and Monthly bulletins from January to December 2010 issued by National Bank of Romania

In 2011 it found a decrease of the number of registered unemployed, but the reality is different: after they are completed 15 months of unemployment benefit, that person is no longer included in the statistics as unemployed (even it not found a job).

The evolution of bad loans is growing. 
Table no. 8.

Pearson correlation coefficient between the evolution of the number of registered unemployed in 2011 and the volume of nonperforming loans in January 2011 - December 2011

\begin{tabular}{|l|l|r|r|}
\hline No. & Month & $\begin{array}{c}\text { Evolution of the number of } \\
\text { registered unemployed in } \\
2011\end{array}$ & $\begin{array}{c}\text { Nonperforming loans in } \\
\text { 2011 (mil lei) }\end{array}$ \\
\hline 1. & Ian & 614,976 & 65139,20 \\
\hline 2. & Feb & 600,308 & 65508,20 \\
\hline 3. & Mar & 539,666 & 65370,40 \\
\hline 4. & Apr & 493,438 & 67441,20 \\
\hline 5. & May & 453,067 & 68304,00 \\
\hline 6. & Jun & 435,961 & 68779,00 \\
\hline 7. & Jul & 435,152 & 70069,30 \\
\hline 8. & Aug & 437,811 & 70757,80 \\
\hline 9. & Sept & 439,928 & 75303,90 \\
\hline 10. & Oct & 444,000 & 75419,30 \\
\hline 11. & Nov & 454,978 & 75793,50 \\
\hline 12. & Dec & 461,013 & 75020,70 \\
\hline
\end{tabular}

Source: created based on data from registered unemployment statistics operative situation issued by National Agency of Employment at 31 December 2011 and Monthly bulletins from January to December 2011 issued by National Bank of Romania

The chart corresponding to table 8 is presented below:

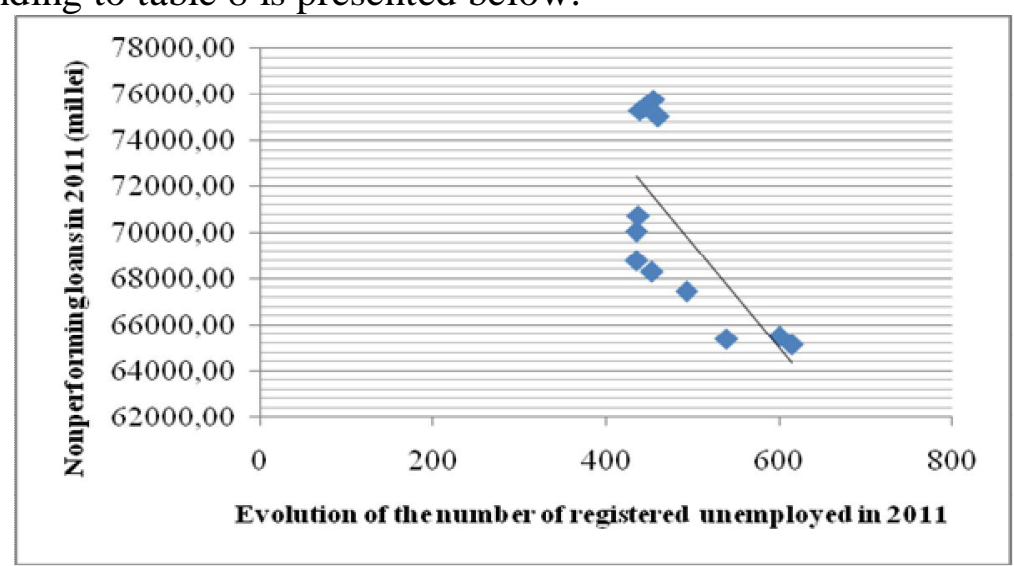

Figure no. 13.

Source: created based on data from registered unemployment statistics operative situation issued by National Agency of Employment at 31 December 2011 and Monthly bulletins from January to December 2011 issued by National Bank of Romania

\section{Analysis of the correlation between the unemployment rate and non-performing loans using the ,Pearson” correlation coefficient}

Pearson correlation coefficient is a dimensionless index ranging between [-1 to 1] and reflects the extent of a linear relation between two sets of data.

The study is based on data from January 2008 - December 2011, and for their interpretation we used statistical methods, which allowed the calculation of the correlation coefficient between the two variables: the independent variable - unemployment rate dependent variable - the volume of nonperforming loans.

In this effect, in order to obtain linear correlation between the two data sets, we used Pearson correlation coefficient. 
Pearson correlation coefficient indicates the expansion of the relating degree through a number between 1.00 and - 1.00. Correlation is made up of pairs of scores (outcomes) for each piece of information from the sample; each piece of information has a pair of scores, one for each of the two variables from which the correlation is composed of. A correlation of one indicates a perfect relating, so if we know that the outcome has the highest score on one variable, we also know that it has the same score over the other. With a negative correlation, they would imply each other in reverse proportion. A correlation of less than one, either positive or negative, indicates the fact that each result of a pair has the same score on the other and draws her less than perfect, so the highest score of a variable in a positive correlation could be accompanied by an average score on the other variable. The fact that the relating exists through a correlation, as it was shown, does not allows us to conclude that the relationship is causal. Often the relationship is the result of a third variable or a combination of other variables. Whether the relating is causal, a correlation allows prediction; therefore, such relating is extremely useful.

In the case of Romanian banking system, we would obtain the following Pearson correlation coefficient between interest rate and volume of deposits based on the following formula:

$$
r=\frac{\sum_{i=1}^{n}\left(X_{i}-\bar{X}\right)\left(Y_{i}-\bar{Y}\right)}{\sqrt{\sum_{i=1}^{n}\left(X_{i}-\bar{X}\right)^{2}} \sqrt{\sum_{i=1}^{n}\left(Y_{i}-\bar{Y}\right)^{2}}} .
$$

- If the Pearson coefficient correlation result is negative then $\rightarrow$ a high correlation where $\mathrm{x}$ increases and y decreases;

- If the coefficient is positive then the result is a direct correlation where both $\mathrm{x}$ and $\mathrm{y}$ increase;

- If the result coefficient $=0$ then there is a weak correlation.

The tables 5,6,7,8 show the graphic representations of correlation between variable $\mathrm{X}$ - the unemployment rate $\mathrm{Y}$ - volume of nonperforming loans from Romania.

Pearson's correlation

\begin{tabular}{|l|l|l|l|l|}
\hline Year & 2008 & 2009 & 2010 & 2011 \\
\hline Pearson's correlation index & 0,379182 & 0,986286 & $-0,93293$ & $-0,70272$ \\
\hline
\end{tabular}

We calculated the correlation index for each year (2008, 2009 and 2010, 2011) and found the following:

- in the year 2008: the unemployment rate increased from one month to another, and the volume of nonperforming loans also increased. Correlation coefficient is positive, which means that there is a direct connection between the two variables: if unemployment rate increases, the volume of nonperforming loans increases also.

- in the year 2009: the unemployment rate increased from one month to another, and the volume of nonperforming loans also increased. Correlation coefficient is positive and approaches 1, which means that there is a tight direct relationship between the two variables.

- in the years 2010 and 2011: the unemployment rate increased till May, only to decrease in June. This is irrelevant because, as mentioned in the section: "NATIONAL REGULATIONS REGARDING UNEMPLOYMENT" unemployment benefit is given to unemployed people in the period between 6 months and 15 months. So between the years 2008, 2009 and 2010 there were massive layoffs of employees due to bankruptcies of firms and dismissal of public sector employees due to the effects of economic crisis. They have received unemployment benefit for a minimum period between 6 months and a maximum of 15 months. In this period, these persons were registered at the National Agency for Employment. After finishing the period in which the unemployment people were given the unemployment benefit (which began in June of the year 2010), the unemployed no longer appeared in the records of the National Agency for Employment, although they couldn't find a job (the Romanian law does not require the 
compulsory of recording). Basically the real number of unemployed in Romania is much higher than that provided by the National Agency for Employment in the official documents. This anomaly is demonstrated also by calculating the Pearson correlation coefficient, which in the year 2010 is -0.93293 and in 2011 is $-0,70272$. These two years are the only years that registered negative values, which is incorrect. To correctly calculate the real Pearson coefficient in 2010 and 2011, we need a real statistics of the number of unemployed people in Romania. This would require a change in the law to make it compulsory to register the unemployed at the National Agency for Employment, even if they ended the period in which they were given the unemployment benefit.

\section{Conclusions}

Banking systems from Central and Eastern Europe needs to do front to nonperforming loans even if economic growth is weak. In 2010, nonperforming loans have reached the maximum, but the banks seem capitalized enough to make front.

Non-performing loan (NPL) ratios appeared to peak in 2010, in the region and the banks appear sufficiently capitalized to absorb the growth reference.

From the experience of previous global crisis the report nonperforming loans in total loans remain high for several years after the beginning of the crisis.

After analyzing the correlation between unemployment rate and nonperforming loans in Romania, results that there is a strong correlation between unemployment rate and nonperforming loans, this means that by increasing unemployment rate, it increases also nonperforming loans. A strong correlation is being recorded especially in the years 2009 and 2010 . The only year where the correlation is not so tight is 2008 - year of the beginning of the crisis (the first half of that year was the period that emergenced crisis period).

\section{References}

1. Asghar A., Daly K., 2010. Macroeconomic determinants of credit risk: Recent evidence from a cross country study, International Review of Financial Analysis, Volume 19, Issue 3, June, pp. 165-171

2. Avery R.B., Calem P.S., Canner G.B., 2004. Consumer credit scoring: Do situational circumstances matter?, Journal of Banking and Finance, vol. 28, issue 4, April, pp. 835-856

3. Carling K., Jacobson T., Lindé J., Roszbach K., 2007. Corporate credit risk modeling and the macroeconomy, Journal of Banking and Finance, vol. 31, issue 3, March, pp. 845-868

4. Foos D, Norden L., Weber M., 2010. Loan growth and riskiness of banks, Journal of Banking \& Finance, Vol. 34, June, pp. 2929-2940

5. Haas R., van Lelyveld I., 2006. Foreign banks and credit stability in Central and Eastern Europe: A panel data analysis, Journal of Banking and Finance, 30, pp.1927-1952

6. Haselmann R., Wachtel P., 2007. Risk taking by banks in the transition countries, Comparative Economic Studies, 49, pp. 411-429

7. Iuga I., Roşca T., 2005. Monedă şi credit (Currency and credit), Risoprint Publishing House, Cluj Napoca

8. Gómez-Valle L., Martínez-Rodríguez J., 2008, Modelling the term structure of interest rates: An efficient nonparametric approach, Journal of Banking \& Finance, Volume 32, Issue 4, April, pp.614-623.

9. Socol A., Iuga I., 2010. Study of correlation between average interest rate and nonperforming loans in the Romanian banking system during 2006 - February 2010, Annals of University from Oradea, Economic sciences, TOM XIX, 2nd ISSUE / DECEMBER

10. Law no. 76 din 16/01/2002 regarding the unemployment insurance system and employment stimulation Published in Official Gazette of Romanian Part I no. 103 from 06/02/2002 
11. Emergency Ordinance no. 99/2006 on Credit Institutions and Capital Adequacy Published in Official Gazette of Romania, no. 1027/2006

12. National Bank of Romania - Monthly bulletins, January - December 2006-2011 available at: http://www.bnro.ro/Publicatii-periodice-204.aspx

13. Registered unemployment statistics operative situation issued by National Agency of Employment at 31 December 2011 available at: http://www.anofm.ro/situatia-operativa-asomajului-inregistrat-la-data-de-31-12-2010

14. http://www.imf.org - International Monetary Fund, Global Financial Stability Report, 2010

15. http://www.imf.org - International Monetary Fund, Regional Economic Outlook, 2010

16. http://www.bnr.ro - National Bank of Romania, Financial Stability Report, 2010 